UNIVERSIDADE TECNOLÓGICA FEDERAL DO PARANÁ DIRETORIA DE PESQUISA E PÓS-GRADUAÇÃO ESPECIALIZAÇÃO EM GESTÃO AMBIENTAL EM MUNICÍPIOS

MANUELLA ANDRADE SWIERCZYNSKI

\title{
PROJETO DE AÇÃO SOCIAL ALIADO A EDUCAÇÃO AMBIENTAL NA ESCOLA E SEUS EFEITOS NA COMUNIDADE
}

MONOGRAFIA DE ESPECIALIZAÇÃO

MEDIANEIRA 


\section{MANUELLA ANDRADE SWIERCZYNSKI}

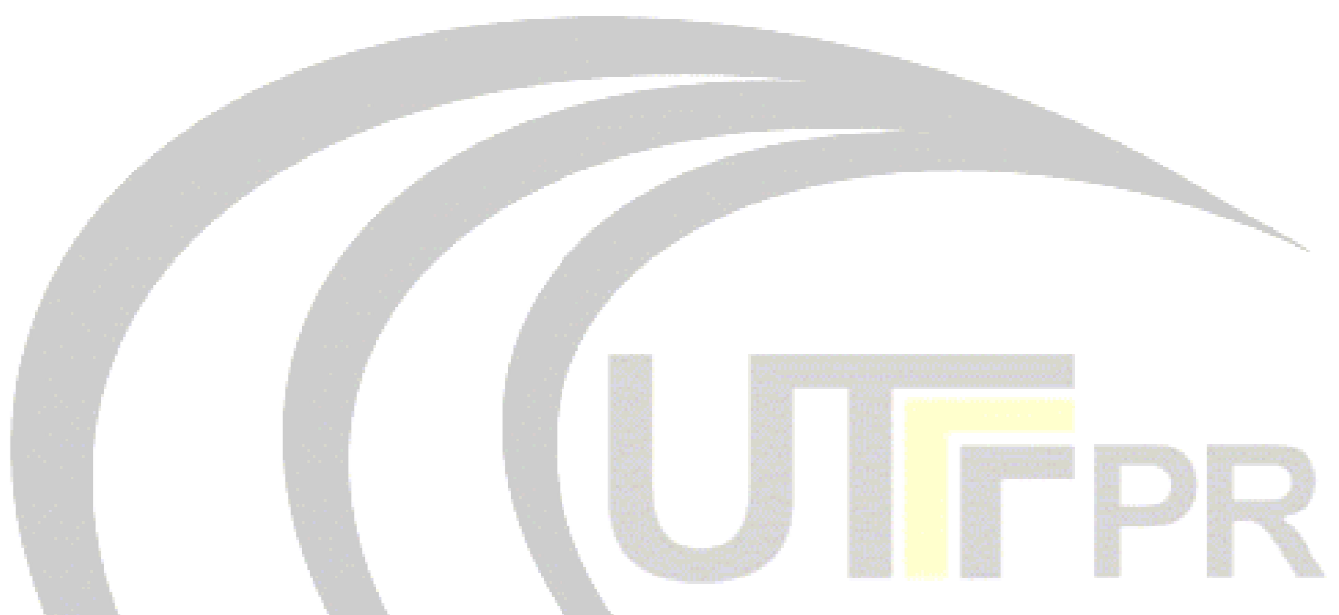

PROJETO DE AÇÃO SOCIAL ALIADO A EDUCAÇÃO AMBIENTAL NA ESCOLA E SEUS EFEITOS NA COMUNIDADE

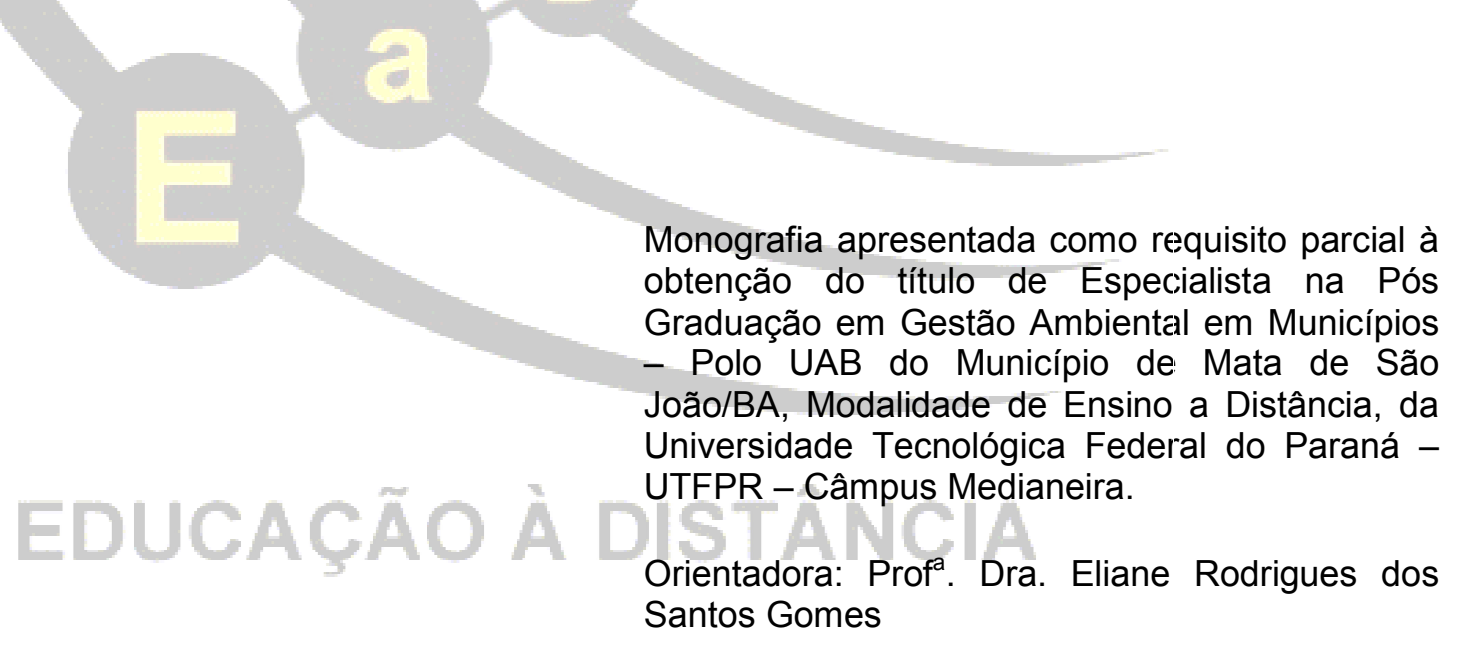

MEDIANEIRA 
Ministério da Educação

Universidade Tecnológica Federal do Paraná

Diretoria de Pesquisa e Pós-Graduação

Especialização em Gestão Ambiental em Municípios

\section{TERMO DE APROVAÇÃO}

Projeto de Ação Social Aliado a Educação Ambiental na Escola e Seus Efeitos na

Comunidade

Por

\section{Manuella Andrade Swierczynski}

Esta monografia foi apresentada às $9 \mathrm{~h}$ do dia 28 de novembro de 2015 como requisito parcial para a obtenção do título de Especialista no Curso de Especialização em Gestão Ambiental em Municípios - Polo de Mata de São João/BA, Modalidade de Ensino a Distância, da Universidade Tecnológica Federal do Paraná, Câmpus Medianeira. O candidato foi arguido pela Banca Examinadora composta pelos professores abaixo assinados. Após deliberação, a Banca Examinadora considerou o trabalho aprovado.

Prof $^{a}$. Dra. Eliane Rodrigues dos Santos Gomes

UTFPR - Câmpus Medianeira

(orientadora)

Prof $^{a}$. Ma. Marlene Magnoni Bortoli

UTFPR - Câmpus Medianeira

- O Termo de Aprovação assinado encontra-se na Coordenação do Curso-. 
Dedico a minha filha Maria Clara e ao esposo Elmar Swierczynski. 


\section{AGRADECIMENTOS}

A Deus, por mais esta oportunidade de evolução.

A minha orientadora professora Dra. Eliane Rodrigues dos Santos Gomes, pelas sábias orientações nos momentos de dúvidas.

A Coordenação do Curso, Professores e demais integrantes dessa digna casa de ensino, pelos conhecimentos que foram transmitidos.

A minha filha Maria Clara e esposo Elmar Swierczynski pela compreensão nas ausências necessárias para minha formação.

A assistente social Hilda Maria Ribeiro Dias pelo imensurável apoio para confecção deste trabalho e pelo inesquecível exemplo profissional.

Ao meu irmão Manoel Andrade pela incansável torcida para meu sucesso.

Aos meus amigos que vibram e comemoram por cada vitória em minha vida.

A EMBASA pelo apoio técnico no estudo do Projeto.

Enfim, sou grata a todos que contribuíram de forma direta ou indireta para realização deste trabalho. 
"A educação é a arma mais poderosa que você pode usar para mudar o mundo". (NELSON MANDELA) 


\section{RESUMO}

SWIERCZYNSKI, Manuella Andrade. Projeto de Ação Social Aliado a Educação Ambiental na Escola e Seus Efeitos na Comunidade. 2015. 36f. Monografia (Especialização em Gestão Ambiental em Municípios). Universidade Tecnológica Federal do Paraná, Medianeira, 2015.

Em virtude do desequilíbrio ocasionado pelas ações humanas sobre o meio ambiente de retirar, consumir e descartar, sem a consciência da conservação ambiental, está sem limites de preservação mínima necessária para garantir a sobrevivência da espécie humana. Esta interação entre homens e ambiente é imprescindível para garantir o desenvolvimento sustentável, entretanto uma das barreiras para atingir este objetivo é o conhecimento mínimo necessário da população humana sobre meio ambiente e sustentabilidade. A Educação Ambiental é um dos caminhos mais eficientes para cobrir a lacuna de conhecimento existente sobre a temática de proteção ao meio ambiente. É evidente que processos por meio do qual o indivíduo e a coletividade constroem valores sociais, conhecimentos, habilidades, atitudes e competências voltadas para a conservação do meio ambiente, assim como o uso de bem comum, devem ser utilizados como valiosas ferramentas de trabalho na conservação do meio ambiente. Esta pesquisa teve como temática a aplicação de Educação Ambiental não formal em uma determinada comunidade através da escola municipal, sensibilizando os alunos a buscarem valores que conduzam uma convivência harmoniosa com o ambiente, desenvolvendo um senso crítico sobre as atitudes que tem levado a destruição dos recursos naturais e várias espécies que habitam o planeta.

Palavras-chave: Meio Ambiente. Sustentabilidade. Conservação. 


\begin{abstract}
SWIERCZYNSKI, Manuella Andrade. Social Action from design Allied Environmental Education in School and Its Effects In the Community. 2015. 36f. Monografia (Especialização em Gestão Ambiental em Municípios). Universidade Tecnológica Federal do Paraná, Medianeira, 2015.

Due to of the imbalance caused by human actions on the environment to pull, consume and discard without awareness of environmental conservation, is boundless minimum necessary preservation to ensure the survival of the human species. This interaction between man and environment is essential to ensure sustainable development, however one of the barriers to achieving this goal is the minimum required knowledge of the human population on the environment and sustainability. Environmental education is one of the most efficient ways to cover the existing knowledge gap about protecting the environment theme. Clearly processes through which the individual and the collectivity build social values, knowledge, skills, attitudes and competencies aimed at the conservation of the environment, as well as the use of the common good, must be used as valuable tools work in conservation environment. This research had as its theme the application of Environmental Nonformal education in a given community through the public school, sensitizing students to seek values that lead a harmonious coexistence with the environment, developing a critical sense of the attitude that has led to destruction of resources natural and various species that inhabit the planet.
\end{abstract}

Keywords: Environment. Sustainability. Conservation. 



\section{LISTA DE FIGURAS}

Figura 1- Foto llustrativa da Escola Municipal São Francisco em Praia do Forte......21

Figura 2- Apresentação da Palestra sobre Resíduos Sólidos.................................. 26

Figura 3 - Coleta de Resíduos Recicláveis ....................................................... 27

Figura 4- Óleo de Fritura Coletado Durante a Gincana pela Equipe Vermelha ...... 27

Figura 5 - Desfile com Roupas Produzidas pelos Alunos Utilizando Material

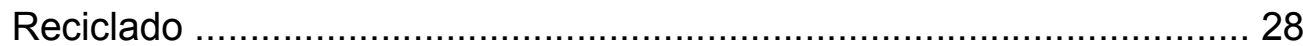

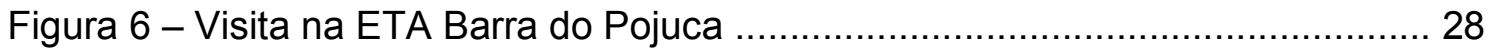

Figura 7- Equipe Vencedora Visitando o Pelourinho em Salvador/Ba .....................31

Figura 8- Equipe Vencedora Visitando o Zoológico em Salvador/Ba ........................32 


\section{LISTA DE TABELAS}

Tabela 1 - Quantidade de Resíduos Sólidos Recicláveis Coletados pelos Alunos ..29

Tabela 2 - Quantidade de Óleos de Fritura Recolhido pelos Alunos........................29

Tabela 3 - Redução de Obstruções em Redes Coletoras de Esgoto em 2015

Comparando-se com o mesmo Período em 2014 …..............................30 


\section{SUMÁRIO}

1 INTRODUÇÃO

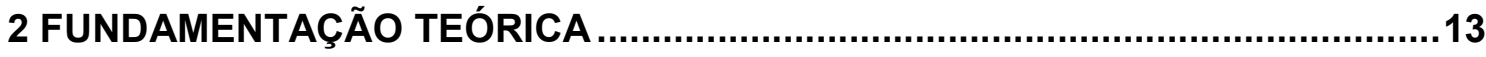

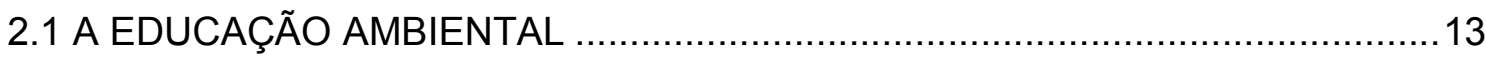

2.2 DESENVOLVIMENTO DE EDUCAÇÃO AMBIENTAL DENTRO DA ESCOLA...15

2.3 EDUCAÇÃO AMBIENTAL NO ENSINO FORMAL E SUA IMPORTÂNCIA ........16

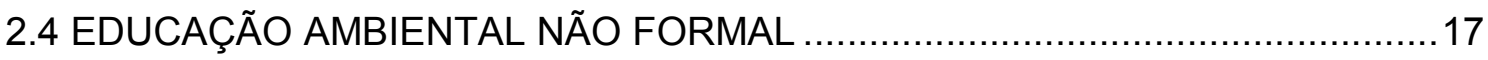

3 PROCEDIMENTOS METODOLÓGICOS........................................................19

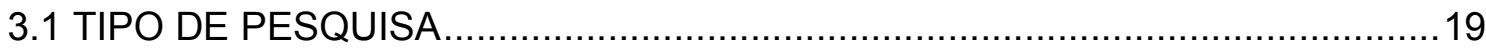

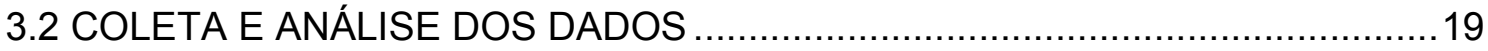

3.3 EMBASA - REALIZAÇÕES DE PROJETOS NA ESCOLA ..............................20

3.4 LOCAL DA APLICAÇÃO DO PROJETO DA EMBASA ……….......................20

4 RESULTADOS E DISCUSSÃO

4.1 RESULTADOS DO PROJETO DESENVOLVIDO NA ESCOLA …...................22

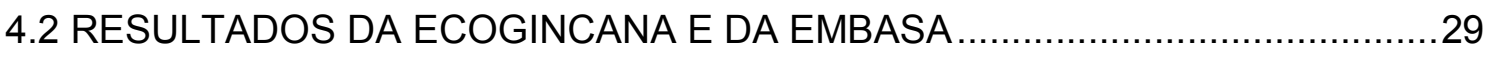

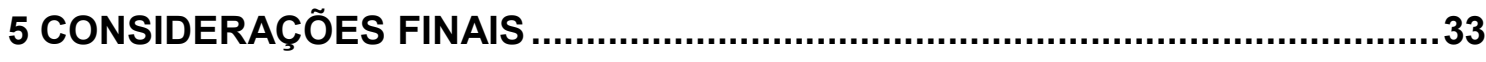

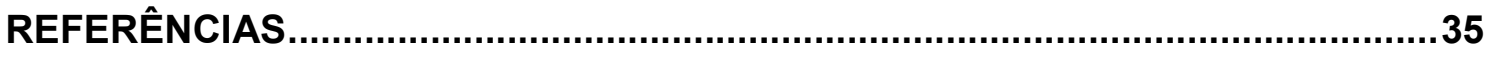




\section{INTRODUÇÃO}

Muito se tem discutido sobre o consumo incessante das gerações atuais, sem atentar para a conservação do meio ambiente, valorizando cada vez mais a necessidade de buscar alternativas para substituir as matérias-primas não renováveis, seja pela reutilização ou reciclagem.

Conforme Varine (2000, p. 62), "a natureza é um grande patrimônio da sociedade. Consequentemente, a Educação Ambiental se torna uma prática social, com a preocupação da preservação dessa sua riqueza". O autor reconhece que o meio ambiente sofre danos em função do crescimento da população, causando decadência na qualidade de vida e incapacidade de sustentação. Agir apenas com denúncias contra agressões à natureza não resolve o mal causado, por isso é necessário um processo com atitudes que promovam a conservação e sustentabilidade do meio.

A poluição atmosférica, a contaminação dos corpos hídricos, a degradação das florestas, além de muitas outras formas de agressão ao meio ambiente, nos dias atuais, são atos comuns. Diante deste cenário, é necessário mudar o comportamento do homem em relação ao meio ambiente, com objetivo de promover um modelo de desenvolvimento sustentável, com reflexos positivos garantindo a sobrevivência com qualidade de vida de todos.

O Desenvolvimento Sustentável busca atender às necessidades da atual geração, sem comprometer a capacidade das futuras gerações em prover suas próprias demandas. Entretanto, é possível preservar com mais intensidade quando se conhece profundamente do assunto para entender as consequências dos atos praticados e o mal que será feito a si mesmo.

A Educação Ambiental tem assumido nos últimos anos o grande desafio de garantir a construção de uma sociedade sustentável, em que se promovam na relação com o planeta e seus recursos, valores éticos como cooperação, solidariedade, generosidade, tolerância, dignidade e respeito à diversidade (CARVALHO, 2006).

As ações sociais que envolvem atividades de educação ambiental favorecem o aprendizado de forma lúdica e diferente, sobre a importância da conservação do 
futuro do planeta. O resultado será a capacidade de reinventar formas de consumir, aperfeiçoando o respeito pelo meio ambiente.

Na visão de Chalita (2002, p. 34), a educação constitui-se na mais poderosa de todas as ferramentas de intervenção no mundo para a construção de novos conceitos e consequente mudança de hábitos. É também o instrumento de construção do conhecimento e a forma com que todo o desenvolvimento intelectual conquistado é passado de uma geração a outra, permitindo, assim, a máxima comprovada de cada geração que avança um passo em relação à anterior no campo do conhecimento científico e geral.

A educação ambiental propõe atingir todos os cidadãos através de um processo participativo que procura conscientizar sobre a problemática ambiental, despertando em cada indivíduo o sentimento de pertencimento, participação e responsabilidade.

Considerando-se a necessidade de buscar novas alternativas para promover o conhecimento de preservação ambiental com resultados práticos, a educação ambiental torna-se uma ferramenta estratégica nesta tarefa. O estudo além da pesquisa teórica visa também apresentar um projeto de ação social efetuado em uma escola municipal na cidade de Mata de São João/BA e quais efeitos a educação ambiental causou na comunidade.

A pesquisa teve como objetivo geral analisar como a Educação Ambiental auxilia no processo de ação social realizado em escolas, com alunos do ensino fundamental em uma comunidade.

Como objetivo específico pretendeu-se: desenvolver estratégias pedagógicas que favoreçam a disseminação do conhecimento sobre a prevenção ambiental, provocar a iniciativa dos alunos quanto ao cuidado com o meio ambiente, transformando-os em multiplicadores permeados na comunidade onde vivem após as ações promovidas durante o período de estudo, utilizando a Educação Ambiental como ferramenta estratégica de trabalho na escola. 


\section{FUNDAMENTAÇÃO TEÓRICA}

Vivenciamos um momento em que a sociedade mundial começa a atentar para os problemas relacionados com o meio ambiente. Aumentaram-se o número de encontros para discutir as questões ligadas à preservação da natureza, ampliou a disseminação de informações quanto à importância desta conservação, entretanto muito trabalho ainda precisa ser feito.

Cada indivíduo é responsável pela construção de um mundo justo e equilibrado ecologicamente, requerendo responsabilidade individual e coletiva, onde será possível criar e aplicar maneiras sustentáveis de interação sociedade natureza.

A identificação dos problemas e implantação de ações de cuidado com o meio ambiente na vida pessoal, em casa, na escola e na comunidade é de suma importância para o desenvolvimento de sua consciência crítica.

Precisa-se estimular o diálogo sobre o tema como forma de expor a problemática do desperdício e despertar o interesse e participação de cada aluno em prol de um mundo melhor, além de estimular a conscientização desde agora para que as crianças de hoje tornem-se adultos conscientes da necessidade pela conservação do meio ambiente.

\subsection{A EDUCAÇÃO AMBIENTAL}

Sabe-se que a Educação Ambiental deve permear todas as classes sociais, e é preciso acontecer tanto no nível formal quanto informal, porém para isto ocorrer é necessário empenho de políticas públicas para que os projetos sejam executados e monitorados com objetivo de avaliar sua eficácia.

Sendo assim, a escola é uma ótima ferramenta de trabalho que deve ser utilizada como meio para atingir o objetivo de disseminar informações e trabalhar a mudança de cultura da comunidade através de projetos sociais com Educação Ambiental. 
A trajetória da presença da educação ambiental na legislação brasileira apresenta uma tendência em comum, que é a necessidade de universalização dessa prática educativa por toda a sociedade.

Segundo Dias (2004), o Brasil é o único país da América Latina que possui uma política específica para Educação Ambiental. Aqui ela tornou-se Lei em 1999, quando foi aprovada a Política Nacional de Educação Ambiental (PNEA), instituída pela Lei $n^{\circ}$ 9.597. Essa lei ganhou regulamentação três anos depois, em junho de 2002, por meio do Decreto $N^{0} 4.281$.

Entretanto, já aparecia em 1973, com o Decreto $n^{\circ} 73.030$, que criou a Secretaria Especial do Meio Ambiente explicitando, entre suas atribuições, a promoção do "esclarecimento e educação do povo brasileiro para o uso adequado dos recursos naturais, tendo em vista a conservação do meio ambiente" (BRASIL, 1973).

A Lei $n^{\circ}$ 6.938, de 31.8.1981, que institui a Política Nacional de Meio Ambiente, também evidenciou a capilaridade que se desejava imprimir a essa dimensão pedagógica no Brasil, exprimindo, em seu artigo $2^{\circ}$, inciso $X$, a necessidade de promover a "educação ambiental a todos os níveis de ensino, inclusive a educação da comunidade, objetivando capacitá-la para participação ativa na defesa do meio ambiente" (BRASIL, 1981).

Contudo, a Constituição Federal de 1988 elevou ainda mais o status do direito à educação ambiental, ao mencioná-la como um componente essencial para a qualidade de vida ambiental. Atribui-se ao Estado o dever de "promover a educação ambiental em todos os níveis de ensino e a conscientização pública para a preservação do meio ambiente" (BRASIL, 1988, art. 225, $\S 1^{\circ}$, inciso $\mathrm{VI}$ ), surgindo, assim, o direito constitucional de todos os cidadãos brasileiros terem acesso à educação ambiental.

Também foi instituída a Lei $n^{\circ} 9.795$ de 27 de abril de 1999 que versa sobre a educação ambiental, instituindo a Política Nacional de Educação Ambiental além de outras providências, e em seu Art. $1^{\circ}$, tem-se a definição de Educação Ambiental como:

Entendem-se por educação ambiental os processos por meio dos quais o indivíduo e a coletividade constroem valores sociais, conhecimentos, habilidades, atitudes e competências voltadas para a conservação do meio ambiente, bem de uso comum do povo, essencial à sadia qualidade de vida e sua sustentabilidade. (BRASIL, 1999) 


\subsection{DESENVOLVIMENTO DE EDUCAÇÃO AMBIENTAL DENTRO DA ESCOLA}

Através de projetos lúdicos desenvolvidos dentro da escola com objetivo de incentivar a participação de alunos, professores e funcionários visam transformá-los em multiplicadores dentro da comunidade com objetivo de sensibilizar os envolvidos na mudança de cultura para agirmos diferente com ações de preservação do meio ambiente.

Effting (2007) aborda que a escola dentro da Educação Ambiental deve sensibilizar o aluno a buscar valores que conduzam a uma convivência harmoniosa com o ambiente e as demais espécies que habitam o planeta, auxiliando-o a analisar criticamente os princípios que tem levado à destruição inconsequente dos recursos naturais e de várias espécies. Explica ainda que, tendo a clareza que a natureza não é fonte inesgotável de recursos, suas reservas são finitas e devem ser utilizadas de maneira racional, evitando o desperdício e considerando a reciclagem como processo vital.

Seguindo este ponto de vista, onde a Educação Ambiental é capaz de tornar o indivíduo em um cidadão participante da discussão sobre meio ambiente, Reigota (2009, p. 15) destaca os princípios da educação:

[...] o questionamento das certezas criadas; a criatividade no desenvolvimento de metodologias e temáticas que levam a descobertas e vivências; a inovação no que tange o relacionar a questão ambiental com a vida cotidiana, com o estímulo sobre a prática da ciência, e; crítica, no que diz respeito a discursos e práticas que desconsideram o discernimento e a possibilidade de intervenção de pessoas e grupos. (REIGOTA, 2009, p. 15)

Para o desenvolvimento da educação ambiental, faz-se necessário agir nos processos de educação trazendo a importância da vinculação escola, família, comunidade, a fim de que haja sensibilização e, de forma mais abrangente, o despertar para a percepção afetiva do ambiente.

As ações socioeducativas desenvolvidas na escola objetivam possibilitar ao corpo docente e discente uma melhor compreensão do seu papel e de sua responsabilidade com o meio ambiente. Jacobi (2003) fala que a educação ambiental deve ser vista como um processo de permanente aprendizagem que 
valoriza as diversas formas de conhecimento e forma cidadãos com consciência local e planetária.

As mudanças comportamentais não acontecem apenas com a teoria, demandando por parte da escola o exemplo em processos e ações extra aula que estejam de acordo com os conteúdos abordados pelos professores. A simples repetição de conceitos teóricos não é suficiente para a construção de uma nova consciência em relação ao meio ambiente.

\subsection{EDUCAÇÃO AMBIENTAL NO ENSINO FORMAL E SUA IMPORTÂNCIA}

Segundo Mendes e Vaz (2009), embora a Educação Ambiental (EA) não seja uma disciplina escolar nem responsabilidade da escola básica, ela pode ser trabalhada por meio de iniciativas pessoais e de grupos multidisciplinares de professores. No Brasil, há registros sobre iniciativas isoladas de inserção de temas ambientais no ensino formal a partir da década de 1950.

Abordando sobre Educação Ambiental no Ensino Formal, reporta-se novamente a Lei $n^{\circ} 9.795$ de 27 de abril de 1999 (BRASIL, 1999), onde no Art. $9^{\circ}$ tem-se o entendimento pelo contexto do tema e engloba a educação básica, a educação superior, educação especial, educação profissional e educação de jovens e adultos.

Nesta mesma lei, em seus Artigos $10^{\circ}$ e $11^{\circ}$, indica que a educação ambiental deve ser aplicada como uma prática educativa integrada, contínua e permanente em todos os níveis e modalidades do ensino formal, constando dos currículos de formação de professores e em todos os níveis e em todas as disciplinas.

Conhecendo melhor a legislação, tem-se transcrito o que preconiza os artigos $9^{\circ}$ ao $12^{\circ}$, sobre educação ambiental no ensino formal, na Lei $n^{\circ} 9.795 / 99$ :

Art. $9^{\circ}$ Entende-se por educação ambiental na educação escolar a desenvolvida no âmbito dos currículos das instituições de ensino públicas e privadas, englobando:

I - educação básica:

a) educação infantil;

b) ensino fundamental e

c) ensino médio;

II - educação superior;

III - educação especial; 
IV - educação profissional;

$\mathrm{V}$ - educação de jovens e adultos.

Art. 10. A educação ambiental será desenvolvida como uma prática educativa integrada, contínua e permanente em todos os níveis e modalidades do ensino formal.

$\S 1^{\circ} \mathrm{A}$ educação ambiental não deve ser implantada como disciplina específica no currículo de ensino.

$\S 2^{2}$ Nos cursos de pós-graduação, extensão e nas áreas voltadas ao aspecto metodológico da educação ambiental, quando se fizer necessário, é facultada a criação de disciplina específica.

$\S 3^{\circ}$ Nos cursos de formação e especialização técnico-profissional, em todos os níveis, deve ser incorporado conteúdo que trate da ética ambiental das atividades profissionais a serem desenvolvidas.

Art. 11. A dimensão ambiental deve constar dos currículos de formação de professores, em todos os níveis e em todas as disciplinas.

Parágrafo único. Os professores em atividade devem receber formação complementar em suas áreas de atuação, com o propósito de atender adequadamente ao cumprimento dos princípios e objetivos da Política Nacional de Educação Ambiental.

Art. 12. A autorização e supervisão do funcionamento de instituições de ensino e de seus cursos, nas redes pública e privada, observarão o cumprimento do disposto nos artigos 10 e 11 da Lei 9.795/99. (BRASIL, 1999).

Gauthier et al., (1998), diz que apesar dessas iniciativas, a EA tem sido introduzida nos ambientes formais de ensino sem uma maneira sistematizada de registro. Essa sistematização poderia agregar valor para a formação de um acervo de conhecimentos sobre a EA Formal e, consequentemente, para o crescimento da pesquisa nessa área.

\subsection{EDUCAÇÃO AMBIENTAL NÃO FORMAL}

Guimarães e Vasconcelos (2006), cita que a educação não formal por ter uma organização espaço-tempo mais flexível, possui um importante papel para a ampliação da cultura científica e humanística. Entretanto, para ampliar sua atuação, é importante que estes espaços estabeleçam uma forte parceria com as escolas, já que estas são instituições com maior capacidade de promover a sistematização com continuidade do trabalho educativo de intervenção na sociedade.

O art. $13^{\circ}$ da Lei № 9795 (BRASIL, 1999), define educação ambiental não formal como as ações e práticas educativas voltadas à sensibilização da coletividade sobre as questões ambientais e à sua organização e participação na defesa da qualidade do meio ambiente. 
Além disso, também proporcionando suporte teórico, o art. $13^{\circ}$ da Lei $\mathrm{N}^{\circ}$ 9795/99, apresenta os princípios básicos da educação ambiental não formal que deverão ser incentivados pelo Poder Público em níveis federal, estadual e municipal:

\footnotetext{
I - a difusão, por intermédio dos meios de comunicação de massa, em espaços nobres, de programas e campanhas educativas, e de informações acerca de temas relacionados ao meio ambiente;

II - a ampla participação da escola, da universidade e de organizações nãogovernamentais na formulação e execução de programas e atividades vinculadas à educação ambiental não-formal;

III - a participação de empresas públicas e privadas no desenvolvimento de programas de educação ambiental em parceria com a escola, a universidade e as organizações não-governamentais;

IV - a sensibilização da sociedade para a importância das unidades de conservação;

V - a sensibilização ambiental das populações tradicionais ligadas às unidades de conservação;

$\mathrm{VI}$ - a sensibilização ambiental dos agricultores;

VII - o ecoturismo. (BRASIL, 1999).
}

Diante do contexto e definições, nota-se que a educação ambiental deve ter como base o pensamento crítico e inovador, em qualquer tempo ou lugar, em seu modo formal e não formal, que promovam a transformação e a construção da sociedade de forma individual e coletiva. A EA tem o propósito de transformar cidadãos com consciência local e planetária, agregando valor ao conhecimento pela sustentabilidade e conservação do meio em que vivem. 


\section{PROCEDIMENTOS METODOLÓGICOS}

\subsection{TIPO DE PESQUISA}

Este trabalho baseia-se num estudo qualitativo. De acordo com Martins (2008, p. XI), uma avaliação qualitativa "[...] é caracterizada pela descrição, compreensão e interpretação de fatos e fenômenos, em contrapartida à avaliação quantitativa, denominada pesquisa quantitativa, onde predominam mensurações". A estratégia utilizada, estudo de caso, pode ser descrita da seguinte forma:

[...] uma investigação empírica que pesquisa fenômenos dentro de seu contexto real (pesquisa naturalística), onde o pesquisador não tem controle sobre eventos e variáveis, buscando apreender a totalidade de uma situação e, criativamente, descrever, compreender e interpretar a complexidade de um caso concreto. Mediante um mergulho profundo e exaustivo em um objeto delimitado - problema de pesquisa - o Estudo de Caso possibilita a penetração na realidade social, não conseguida plenamente pela avaliação quantitativa. (MARTINS, 2008, p. XI).

Foi escolhido para pesquisa um Projeto com enfoque no tema de estudo e com ótimas oportunidades para trabalhar o desenvolvimento da Educação Ambiental em uma comunidade através da escola.

\subsection{COLETA E ANÁLISE DOS DADOS}

A coleta dos dados foi realizada através da quantificação dos resíduos recolhidos pela Cooperativa assim como o acompanhamento na redução de obstruções de rede de esgoto pela Embasa. 
A população amostrada foi a partir dos alunos das quatro turmas das $5^{\mathrm{a}}$ a $8^{\mathrm{a}}$ séries do Ensino Fundamental II, onde em um total de 104 alunos que participaram das atividades.

Apresentados os procedimentos metodológicos, a etapa seguinte consistiu em descrever os resultados da pesquisa relativa ao Projeto EMBASA NA ESCOLA, aplicado numa Escola Municipal de Mata de São João/BA.

Os dados foram analisados de forma que apresente os resultados alcançados e apontem na conclusão uma síntese de roteiro de trabalho que possa ser desenvolvido em escolas municipais que atendam pequenas comunidades.

\subsection{EMBASA - REALIZAÇÕES DE PROJETOS NA ESCOLA}

A EMBASA - Empresa Baiana de Águas e Saneamento desenvolve há mais de 15 anos o Projeto EMBASA NA ESCOLA - Reciclando Hábitos, que possui o objetivo de promover ações de educação ambiental não formal, disseminando conhecimentos através de multiplicadores que são informados nas comunidades visitadas.

O foco do trabalho normalmente são escolas públicas municipais e estaduais, localizadas em comunidades que possuem como meio de subsistência o meio ambiente, ou seja, atividades pesqueiras, artesanatos, entre outros.

Este projeto tem apresentado resultados muito positivos para a empresa e sociedade, sendo responsável pela iniciação de outros projetos corporativos tais como o OGR - Óleo e Gorduras Residuais que atua diretamente na coleta deste resíduo evitando obstruções nas redes coletoras de esgoto e reduzindo grandes danos ao meio ambiente, Ações de Apoio ao Combate da Dengue, Visitas Técnicas nas Estações de Tratamento de Água e Esgoto, entre outros.

\subsection{LOCAL DA APLICAÇÃO DO PROJETO DA EMBASA}


O projeto foi trabalhado na Escola Municipal São Francisco que está localizada em Praia do Forte, município de Mata de São João/BA (Figura 1). A região de Praia do Forte é conhecida como um dos melhores pontos turísticos em função dos grandes complexos hoteleiros além do Projeto Tamar, referência mundial na conservação de tartarugas marinhas.

A escola em que foi desenvolvido o projeto está localizada na Vila de Pescadores e atende a esta comunidade, que inclusive, depende do meio ambiente para sobreviver.

A Escola funciona em tempo integral, atende em média 240 alunos na faixa etária de 06 a 14 anos de idade, da alfabetização a $8^{a}$ série, correspondendo do $1^{\circ}$ ao $9^{\mathrm{a}}$ ano do ensino fundamental I e II.

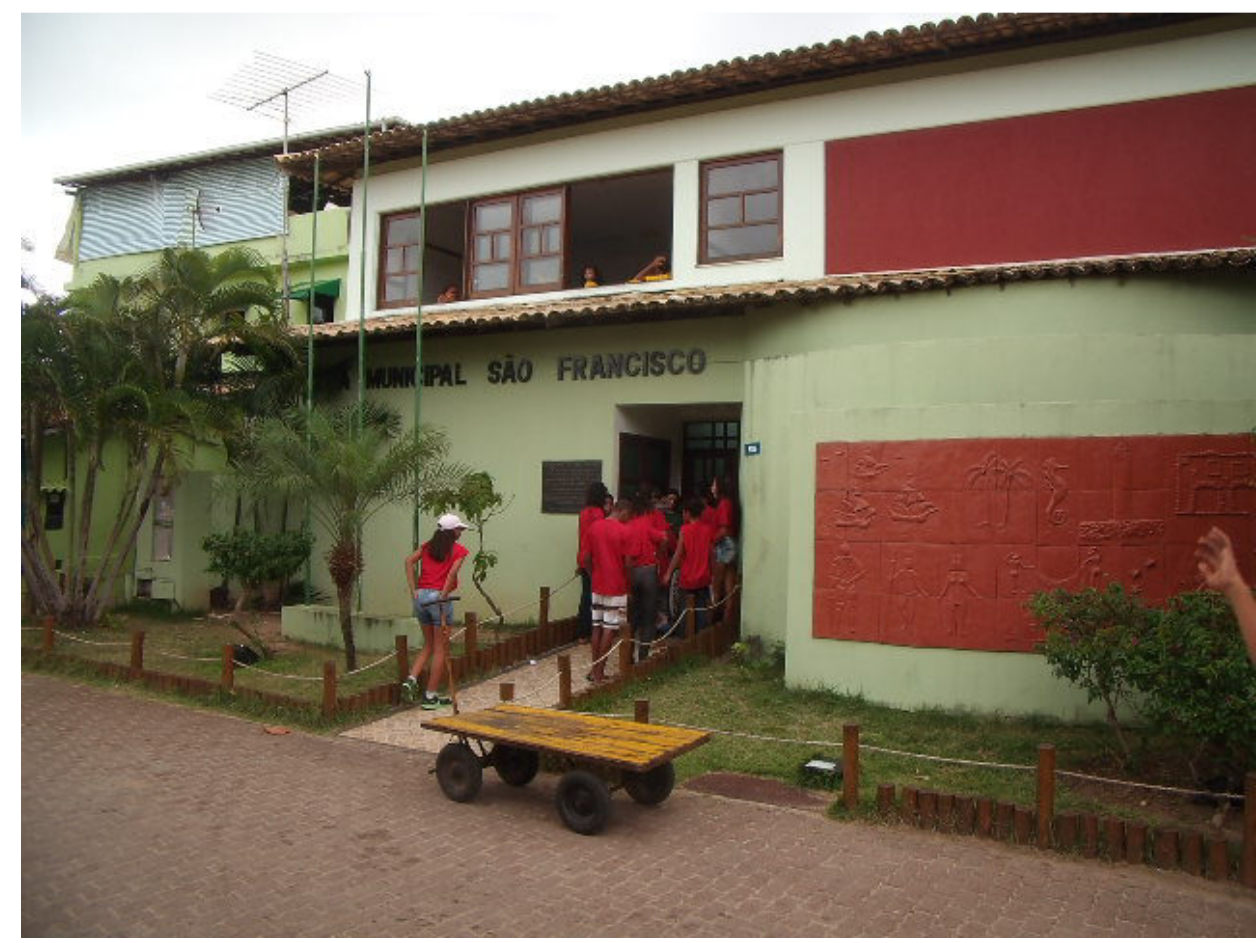

Figura 1- Foto ilustrativa da Escola Municipal São Francisco, na Praia do Forte. 


\section{RESULTADOS E DISCUSSÃO}

O desenvolvimento de novas formas para promover a valorização do meio ambiente através de técnicas que deixem um resultado sistemático e não soluções pontuais são cada vez mais necessárias na eficiência da educação ambiental.

A utilização de oficinas provocando a participação dos estudantes e professores em atividades lúdicas divulgando-se o resultado alcançado como forma de incentivar a continuidade do programa tende a transformar os personagens iniciais das atividades em praticantes das ações ambientalmente corretas, disseminando boas práticas de preservação do meio e bem estar social.

\subsection{RESULTADOS DO PROJETO DESENVOLVIDO NA ESCOLA}

O Projeto Embasa na Escola- Reciclando Hábitos, foi desenvolvido na Escola Municipal de Ensino Fundamental São Francisco, em Praia do Forte, Município de Mata de São João. A parceria surgiu da inquietação dos alunos a partir dos diálogos realizados pela Embasa em março de 2014, na comemoração do dia mundial da água. A empolgação dos alunos foi tamanha que demonstraram o interesse em desenvolver ações para minimizar o desperdício na escola, na casa e na comunidade de Praia do Forte.

A estratégica pedagógica adotada para o projeto foi a da formação pela prática aliada à reflexão, envolvendo diálogos para reflexão conceitual e orientação para inserção da Educação Ambiental na escola.

A proposta foi concebida tomando como referência também os processos de educação ambiental não formal, ou seja, aquele que necessariamente não está atrelado à estrutura curricular. Tal processo permite a identificação de problemas ambientais locais e construção de propostas para superação dos mesmos. A 
utilização de linguagem simples e de metodologias que valorizem a observação e percepção dos envolvidos, assim como de práticas simples que possibilitem reflexão, construção e reconstrução do conhecimento, potencializando ações que já estejam sendo realizadas pelos professores através de um processo pedagógico participativo permanente, que procura transmitir no educando uma consciência crítica sobre a problemática ambiental.

Para o desenvolvimento da educação ambiental, faz-se necessário agir nos processos de educação trazendo a importância da vinculação escola, família, comunidade, a fim de que haja sensibilização e, de forma mais abrangente, o despertar para a percepção afetiva do ambiente.

A estratégia metodológica do Projeto foi composta de 05 etapas conforme descritos na Quadro 1.

\begin{tabular}{|c|c|c|c|}
\hline ETAPA & OBJETIVO & PERIODICIDADE & METODOLOGIA \\
\hline $1^{a}$ & $\begin{array}{l}\text { Construir as ações com a } \\
\text { participação da EMBASA* e } \\
\text { escola (coordenadora } \\
\text { pedagógica, professores e } \\
\text { alunos) }\end{array}$ & $\begin{array}{l}\text { Toda quarta-feira à } \\
\text { tarde }\end{array}$ & $\begin{array}{l}\text { Reunir a Embasa com os } \\
\text { professores onde são } \\
\text { trabalhadas as demandas dos } \\
\text { alunos trazidas da sala de aula }\end{array}$ \\
\hline $2^{a}$ & Contextualização dos Temas & Semanalmente & $\begin{array}{l}\text { Foram realizados diálogos em } \\
\text { sala de aula pela Embasa e } \\
\text { parceiros de Praia do Forte }\end{array}$ \\
\hline $3^{a}$ & $\begin{array}{l}\text { Desenvolvimento de estudos } \\
\text { e pesquisas pelos alunos }\end{array}$ & $\begin{array}{l}01 \text { vez durante o } \\
\text { projeto }\end{array}$ & $\begin{array}{l}\text { Realizar visitas de campo na } \\
\text { ETE* }^{*} \text { na ETA* com o objetivo } \\
\text { de potencializar o } \\
\text { conhecimento. }\end{array}$ \\
\hline $4^{a}$ & $\begin{array}{l}\text { Realizar ação prática que } \\
\text { possa minimizar os } \\
\text { problemas identificados } \\
\text { como impactos negativos no } \\
\text { meio ambiente em Praia do } \\
\text { Forte. }\end{array}$ & $\begin{array}{l}01 \text { vez durante o } \\
\text { projeto }\end{array}$ & Realizar ECOGINCANA \\
\hline $5^{a}$ & $\begin{array}{l}\text { Troca do conhecimento entre } \\
\text { as séries e os diversos } \\
\text { Temas, com a realização da } \\
\text { Feira do Conhecimento. }\end{array}$ & $\begin{array}{l}01 \text { vez durante o } \\
\text { projeto }\end{array}$ & $\begin{array}{l}\text { Realizar a Feira do } \\
\text { Conhecimento }\end{array}$ \\
\hline
\end{tabular}

Quadro 1 - Etapas Metodológicas do Projeto.

Fonte: EMBASA, 2014.

(*) ETA: Estação de Tratamento de Água; ETE: Estação de Tratamento de Esgoto; EMBASA - Empresa Baiana de Águas e Saneamento.

O cardápio de temas desenvolvidos durante os diálogos foram oriundos da identificação de problemas ambientais locais e construção de propostas realizadas junto aos alunos. No processo, as demandas oriundas das lacunas de informações e 
conhecimentos apontados pelos professores foram sendo incorporadas a esse cardápio geral.

A metodologia de temas geradores adotada teve como objetivo levar os alunos a perceber o ambiente em que vive e se perceber como parte dele, principalmente nos aspectos relacionados ao saneamento básico, e dessa forma, contribuir para o respeito à escassez dos recursos naturais e as necessidades das próximas gerações. De posse dos Temas os atores passaram a investigar conjunta e sistematicamente com o objetivo de resolver o problema, ou para a tomada de consciência, ou para a produção de conhecimentos.

Os temas escolhidos para trabalhar durante o projeto foram selecionados pelos parceiros envolvidos (escola, comunidade, cooperativa, empresa) e estão apresentados no Quadro 02.

\begin{tabular}{|l|l|c|l|}
\hline SÉRIE & \multicolumn{1}{|c|}{ TEMA GERADOR } & $\begin{array}{l}\text { PROFESSORES } \\
\text { RESPONSÁVEIS }\end{array}$ & \multicolumn{1}{|c|}{ PALESTRANTE } \\
\hline $\mathbf{8}^{\mathbf{0}}$ & De Olho no Óleo & 3 & COOPMARC*/EMBASA* $^{*}$ \\
\hline $\mathbf{7}^{\mathbf{2}}$ & $\begin{array}{l}\text { Consumo Consciente } \\
\text { de Água e Alimento }\end{array}$ & 3 & Nutricionista/ EMBASA \\
\hline $\mathbf{6}^{\mathbf{0}}$ & $\begin{array}{l}\text { Conservação da Flora e } \\
\text { Fauna }\end{array}$ & 4 & Grupo Floresta Sustentável \\
\hline $\mathbf{5}^{\mathbf{0}}$ & $\begin{array}{l}\text { O luxo do lixo (Resíduo } \\
\text { Sólido) }\end{array}$ & 4 & EMBASA \\
\hline
\end{tabular}

Quadro 2 - Temas Geradores do Projeto.

Fonte: EMBASA, 2014.

$\left({ }^{\star}\right)$ COOPMARC - Cooperativa de Materiais Recicláveis de Camaçari; EMBASA - Empresa Baiana de Águas e Saneamento.

A COOPMARC - Cooperativa de Materiais Recicláveis de Camaçari faz parte da Rede Social Óleo Bahia que é formada por entidades de catadores de materiais recicláveis e reutilizáveis e agentes socioambientais, responsável pelo Projeto Rede Socioambiental da Coleta de Óleo de Fritura e Gorduras Residuais na Bahia, patrocinado pela Petrobrás através do Programa Desenvolvimento e Cidadania, tendo como executora a Organização, Associação Pleno Cidadão - ASPEC. 
A escolha destes temas partiu da discussão entre a coordenação do Projeto e dos professores, os quais também representavam a comunidade. Em outros projetos desenvolvidos pela EMBASA já se discutiu estes temas, considerando-se a relevância destes para a aplicação da Educação Ambiental.

Discutir a questão do descarte correto do óleo de cozinha utilizado na cocção de alimentos é de suma importância para conservar o meio ambiente evitando o despejo em drenagens pluviais além de reduzir obstruções causadas por este elemento quando lançado nas redes coletoras de esgoto através do despejo em pias de cozinhas.

O consumo consciente de alimentos promove a consciência pelo desenvolvimento sustentável uma vez que esta comunidade está localizada em uma área de preservação ambiental e precisam do meio ambiente como meio de subsistência.

A conservação da fauna e flora também promove a conscientização para a sobrevivência da comunidade, uma vez que, a atração turística na região também acontece pela Reserva Sapiranga, que mantém um trecho da Mata Atlântica aberto para visitação do público.

A discussão sobre Resíduos Sólidos buscava provocar na comunidade uma reflexão sobre a reciclagem e reuso, temas que ainda são inovadores para eles.

Após a definição dos temas geradores, partiu-se para contextualizá-los através de diálogos realizados por parceiros convidados para assumir o papel de facilitador do processo. Como os alunos teriam que conhecer todos os Temas passou a pesquisar com o objetivo de replicar para as demais séries os conhecimentos obtidos.

Para aperfeiçoar os temas escolhidos foram convidados membros da comunidade, empresa, entre outros que fizessem palestras nas turmas sobre o assunto abordado no trabalho. A figura 2 ilustra um dos registros da palestra sobre Resíduos Sólidos com o título de "O luxo do lixo" que foi promovida pela assistente social Hilda Maria Ribeiro Dias, da empresa EMBASA, provocando o desenvolvimento da consciência ambiental em reciclar e reutilizar. Ao final da palestra os alunos tinham uma percepção muito boa referente ao tema, o que pode também ser conferido com o resultado da coleta de resíduos sólidos recicláveis alcançado na ECOGINCANA realizada na comunidade. 


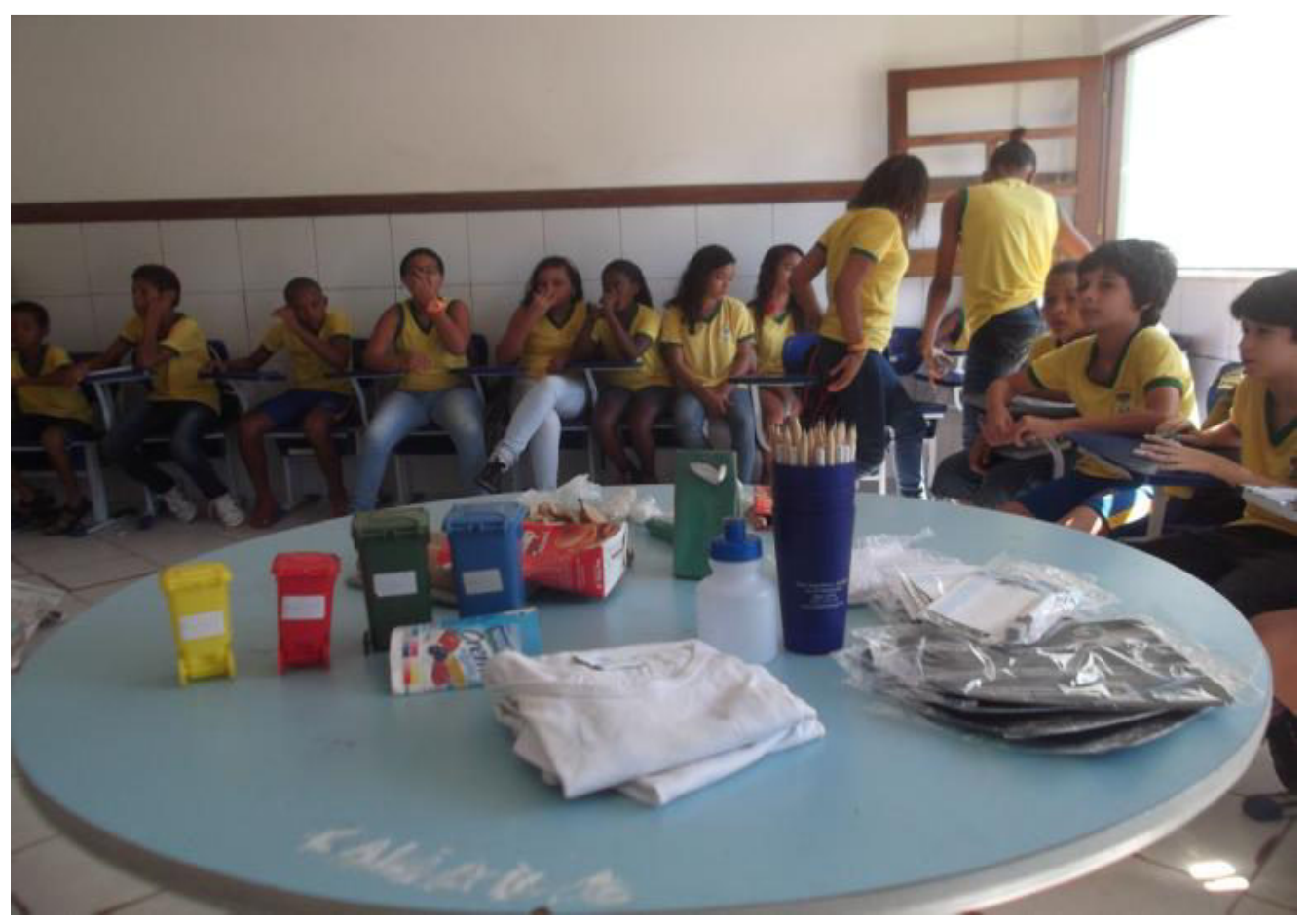

Figura 2 - Apresentação da Palestra Sobre Resíduos Sólidos.

Com o objetivo de possibilitar a interação entre a comunidade escolar, dentro de uma competição saudável, que estimulasse a construção e difusão de conhecimentos voltados para fomentar valores e atitudes para a formação de uma sociedade sustentável, foi realizada a ECOGINCANA.

Distribuídos em quatro equipes (vermelha, amarela, verde e laranja), criando o nome e o grito de guerra receberam as tarefas de:

- Coletar notas fiscais para serem doadas a Instituições Sociais;

- Coletar óleos de fritura (nos pontos comerciais e domiciliares);

- Coletar recicláveis para serem doados à COOPMARC - Cooperativa de Materiais Recicláveis de Camaçari;

- Confeccionar e desfilar com roupas de materiais recicláveis;

- Recitar, dançar e cantar com temas voltados para a sustentabilidade do meio ambiente.

As Figuras 3 a 6 ilustram os resultados obtidos com a ECOGINCANA promovida na comunidade. 


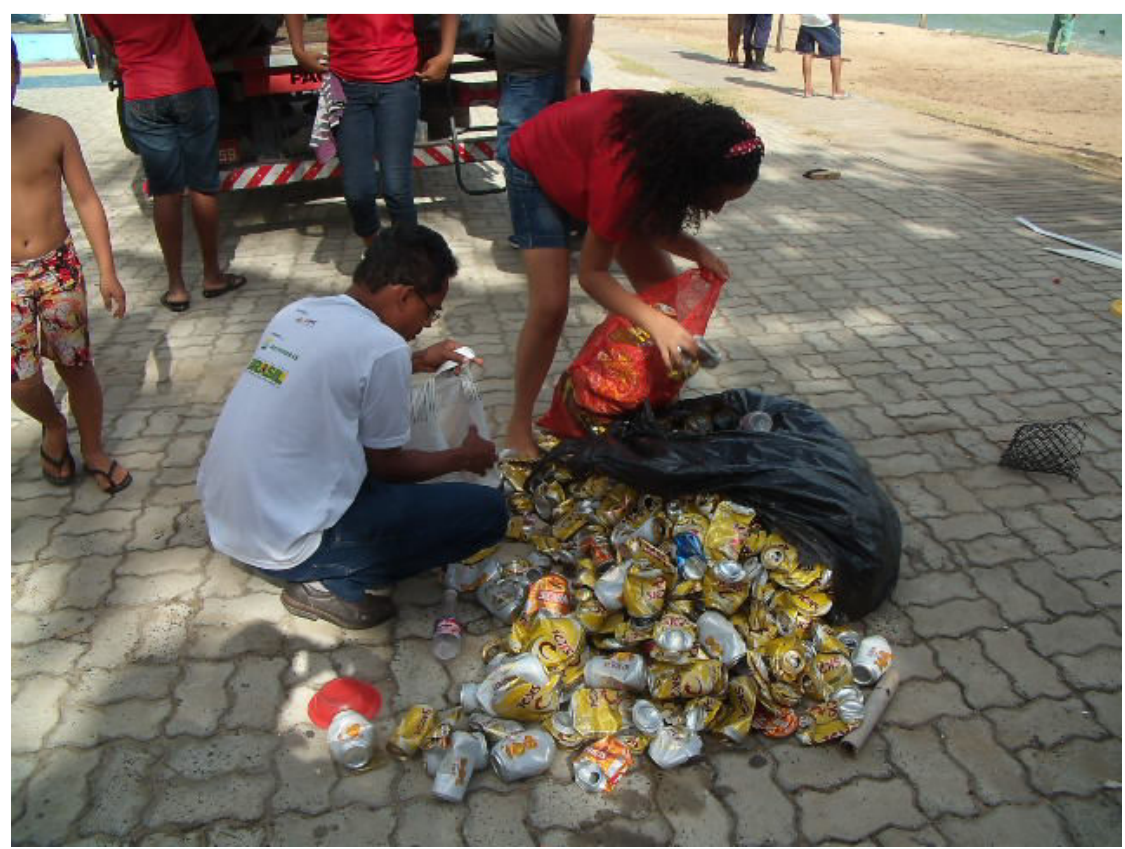

Figura 3- Coleta de Resíduos Recicláveis.

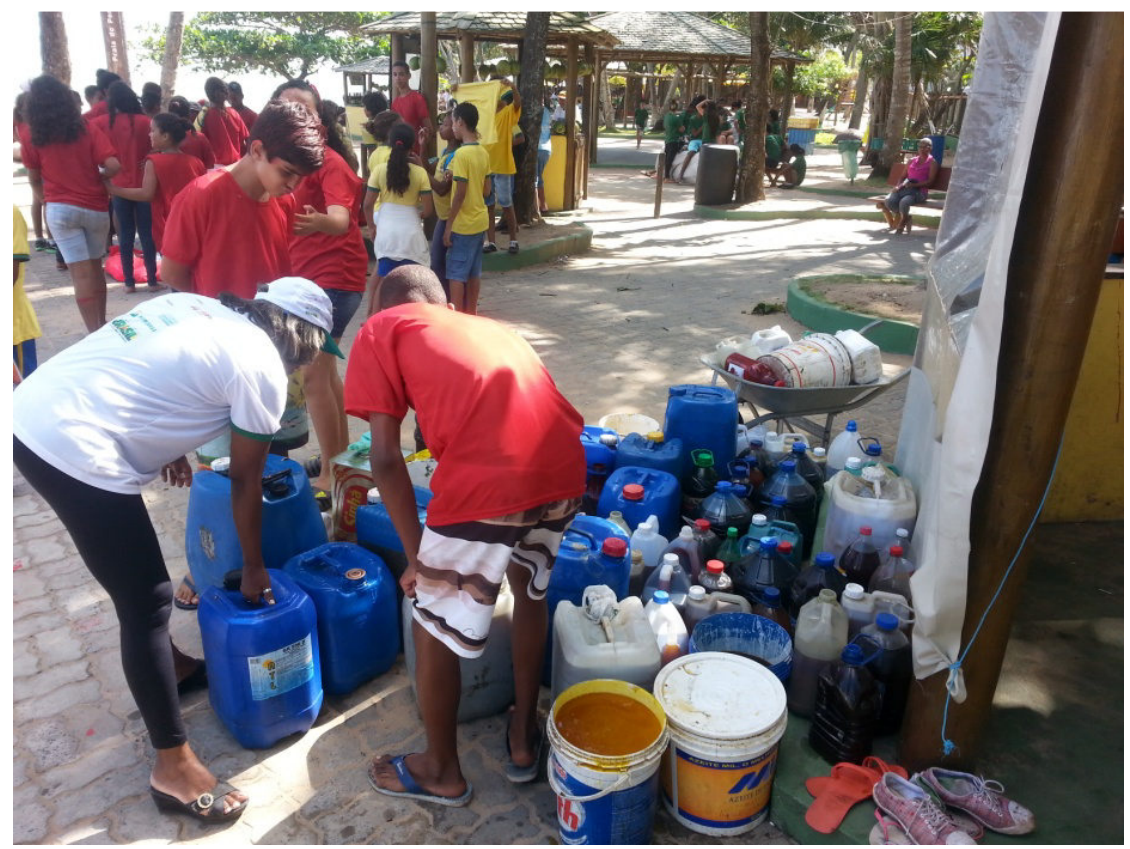

Figura 4- Óleo de Fritura Coletado Durante a Gincana pela Equipe Vermelha. 


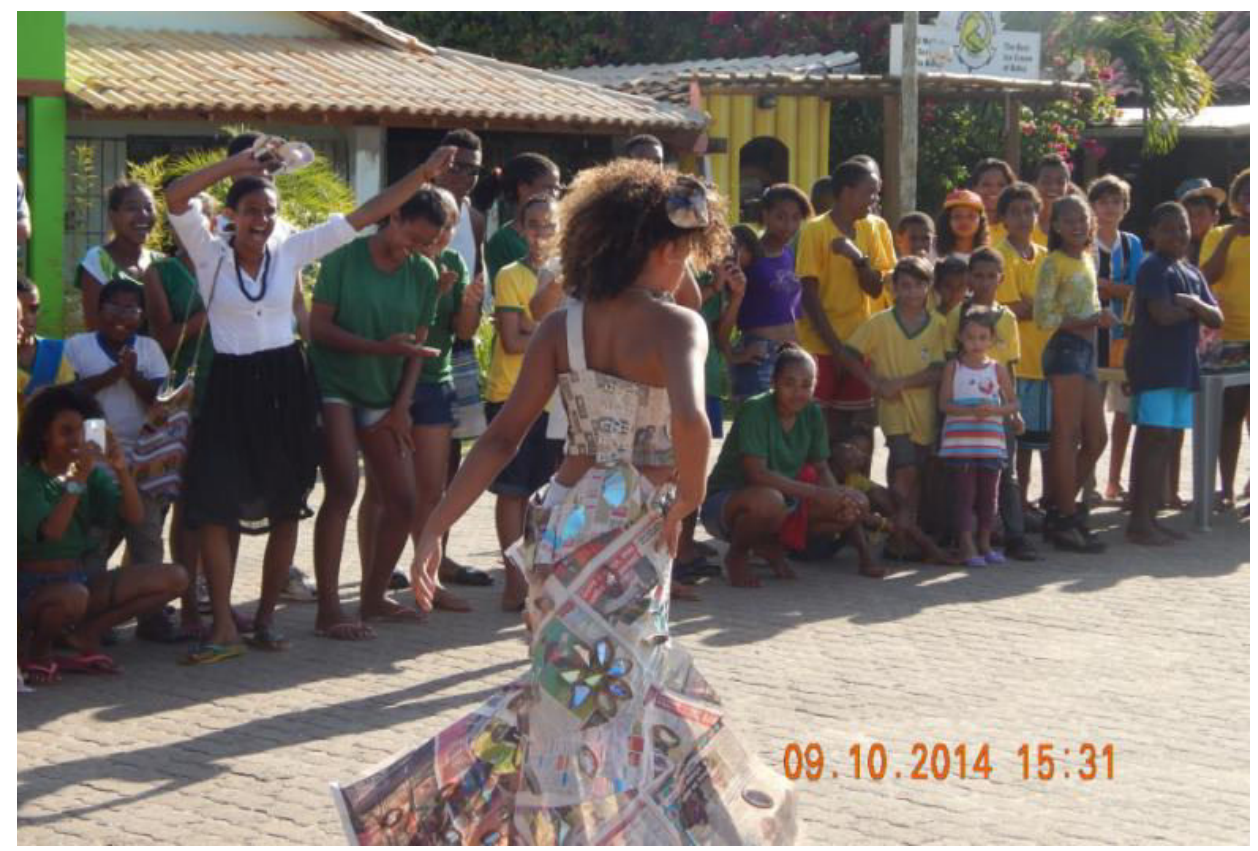

Figura 5 - Desfile com Roupas Produzidas pelos Alunos Utilizando Material Reciclado.

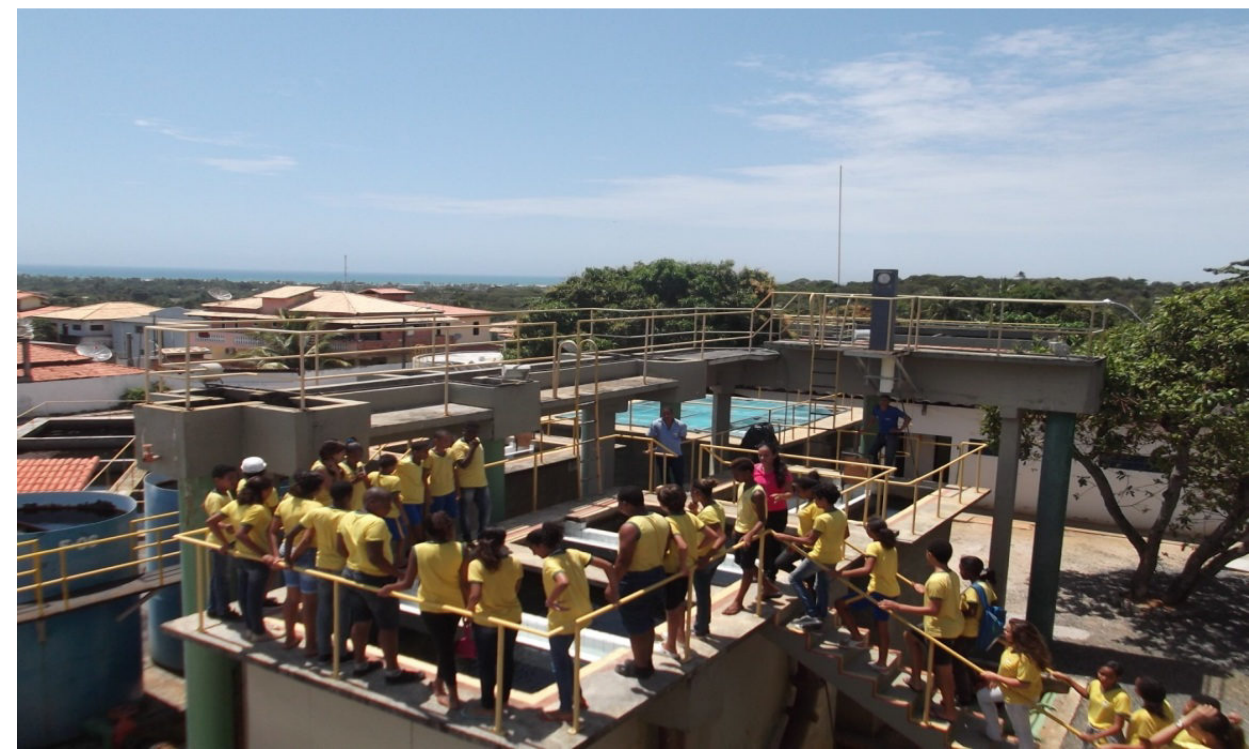

Figura 6 - Visita na ETA Barra do Pojuca

Effting (2007) explica que o processo de sensibilização da comunidade escolar pode fomentar iniciativas que transcendam o ambiente escolar, atingindo tanto o bairro no qual a escola está inserida como comunidades mais afastadas nas quais residam alunos, professores e funcionários. Souza (2000) afirma, inclusive, que o estreitamento das relações intra e extraescolar é bastante útil na conservação do ambiente, principalmente o ambiente da escola. 
Para o encerramento das atividades foram apresentadas pela COOPMARC a estatística dos resíduos sólidos coletados na campanha da ECOGINCANA, além de apurar os resultados do projeto com a EMBASA referente à redução de obstruções nas redes de esgoto.

\subsection{RESULTADOS DA ECOGINCANA E DA EMBASA}

Referente aos resíduos coletados pela ECOGINCANA, nas Tabelas 1 e 2 tem-se o resultado encontrado para quantidade de resíduos sólidos recicláveis e quantidade de óleo de fritura.

Tabela 1 - Quantidade de Resíduos Sólidos Recicláveis Coletados pelos Alunos.

\begin{tabular}{lccccccc}
\hline EQUIPE & Papelão & PET & Alumínio & Ferro & Plástico & Misto & TOTAL \\
\hline VERDE & 341 & 10 & 60 & 34 & 20 & & $\mathbf{4 6 5}$ \\
\hline AMARELO & 562 & & 100 & 500 & 54 & & $\mathbf{1 2 1 5}$ \\
\hline VERMELHA & 300 & & & 184 & & 164 & $\mathbf{6 4 7}$ \\
\hline LARANJA & 299 & $\mathbf{7 4}$ & & 150 & & & $\mathbf{5 2 3}$ \\
\hline TOTAL & $\mathbf{1 5 0 1}$ & $\mathbf{8 4}$ & $\mathbf{1 6 0}$ & $\mathbf{8 6 8}$ & $\mathbf{7 4}$ & $\mathbf{1 6 4}$ & $\mathbf{2 8 5 0}$ \\
\hline
\end{tabular}

Fonte: Dados coletados pela COOPMARC, 2014.

Tabela 2 - Quantidade de Óleos de Fritura Recolhido pelos Alunos.

\begin{tabular}{|c|c|}
\hline EQUIPE & $\begin{array}{l}\text { OGR- Óleo de } \\
\text { Gordura } \\
\text { Residual }\end{array}$ \\
\hline VERDE & 457 \\
\hline AMARELO & 641 \\
\hline VERMELHA & 494 \\
\hline LARANJA & 440 \\
\hline TOTAL (litros) & 2032 \\
\hline
\end{tabular}


A quantidade de resíduos recolhidos foi surpreendente para todas as partes envolvidas no projeto. O resultado da sensibilização ambiental promoveu diversos efeitos na comunidade conforme relacionados a seguir:

1. Sensibilização e envolvimento do corpo docente e discente da Escola Municipal São Francisco no projeto;

2. Redução do volume de óleo de fritura lançado na rede de esgoto operada pela Embasa, com resultado imediato da ECOGINCANA e em longo prazo com a mobilização social.

3. Mapeamento das informações sobre o consumo de óleo realizado pelos alunos através de pesquisa de campo;

4. Instalação de um ECOPONTO para coleta de óleo de frituras de alimentos, na escola para continuar o trabalho de controle de lançamento de óleo nas redes;

5. Benefício social com apoio a inclusão social, com geração de trabalho e renda com a parceria com a COOPEMARC;

6. Atendimento à condicionante da Licença Operacional do Sistema de Esgotamento Sanitário de Praia do Forte pela EMBASA - Empresa Baiana de Águas e Saneamento;

7. Aumento da credibilidade da Embasa com a Secretaria de Planejamento e Meio Ambiente da Prefeitura de Mata de São João e Ministério Público pelo trabalho desenvolvido e os resultados conquistados.

Além dos resultados com a coleta dos resíduos também houve um ganho expressivo na redução de obstruções de esgoto na região de Praia do Forte.

Tabela 3 - Redução de Obstruções em Redes Coletoras de Esgoto em 2015 Comparando-se com o Mesmo Periodo em 2014.

\begin{tabular}{ll}
\hline PERÍODO & $\begin{array}{l}\text { REDUÇÃO DE } \\
\text { OBSTRUÇÕES }\end{array}$ \\
\hline jan/15 & $53 \%$ \\
\hline $\mathrm{fev} / 15$ & $29 \%$ \\
\hline $\mathrm{mar} / 15$ & $92 \%$ \\
\hline $\mathrm{abr} / 15$ & $0 \%$ \\
\hline $\mathrm{mai} / 15$ & $46 \%$ \\
\hline
\end{tabular}

Fonte: Relatório de Controle Estatístico da EMBASA, 2015. 
Em 2014 a região de Praia do Forte teve um aumento de 7\% no número total de ligações de esgoto, com acréscimo de $31 \%$ da quantidade de economias. Mesmo com o aumento significativo do volume coletado de esgoto, após a ação da gincana realizada no mês de Outubro/14, houve uma redução em $45 \%$ dos serviços de desobstrução de esgotos demandados em Praia do Forte no mês Novembro/14. Essa redução de atendimento ocorreu no período do verão de 2015, conforme demonstrado na Tabela 3.

Outro fator importante é que a região de Praia do Forte é um local turístico e na alta estação há uma população flutuante de turistas. Com o aumento de pessoas aumenta-se também o volume de efluente doméstico produzido. Mesmo com o acréscimo de esgoto derivado do verão, o número de ocorrências por obstrução nas redes coletoras de esgoto foi diminuído.

Como premiação para a equipe vencedora da gincana, foi promovido pela Embasa em parceria com a Escola São Francisco um passeio turístico em Salvador, com direito a visita no Pelourinho (Figura 7) que é o Centro Histórico da cidade, Mercado Modelo, Elevador Lacerda, almoço e um passeio no Zoológico da cidade (Figura 8), com intuito de incentivar a todos os alunos e professores envolvidos que continuem promovendo atividades de educação ambiental com exercícios lúdicos e participativos.

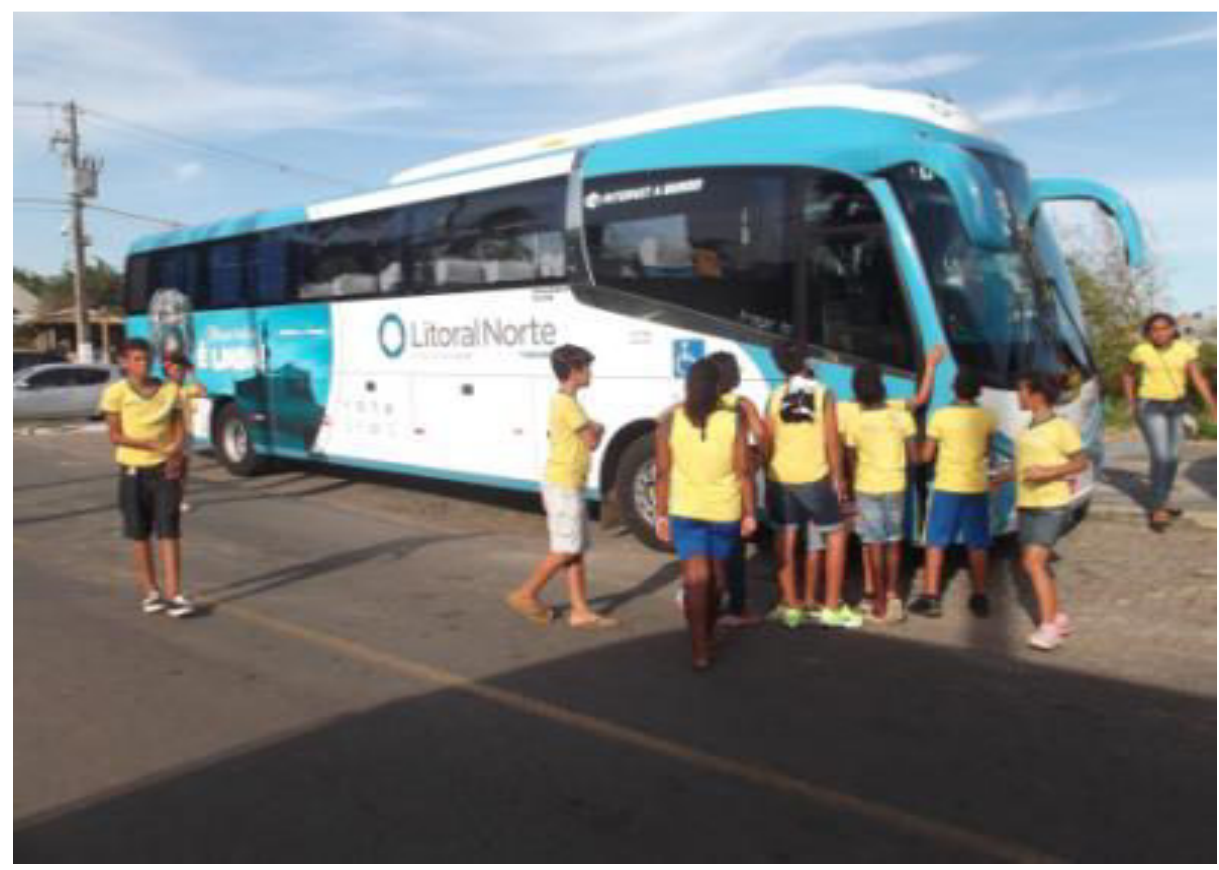

Figura 7- Equipe Vencedora Visitando o Pelourinho em Salvador/BA. 


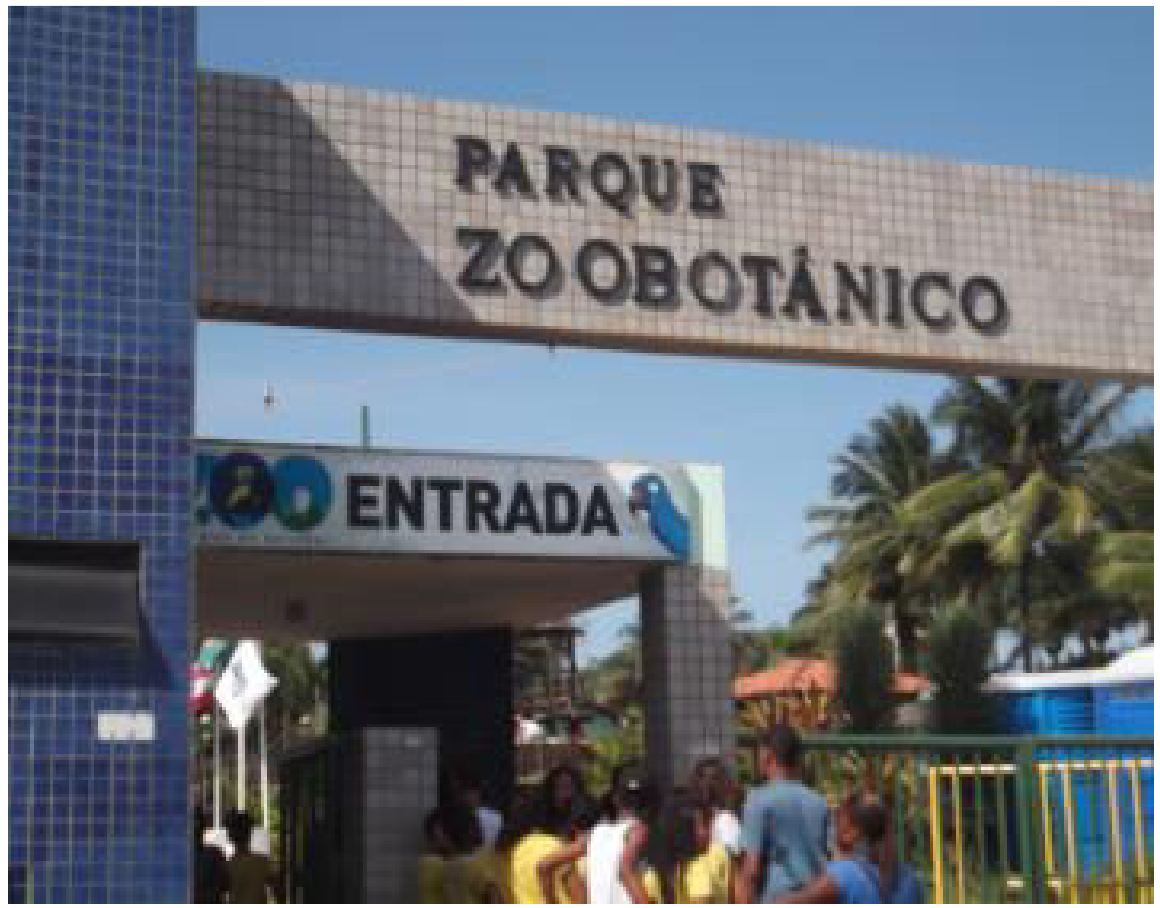

Figura 8- Equipe Vencedora Visitando o Zoológico em Salvador/BA. 


\section{CONSIDERAÇÕES FINAIS}

Com este trabalho, procurou-se demonstrar a importância de se trabalhar com os alunos a preservação e defesa do meio ambiente e identificar os principais problemas ambientais relativos à comunidade de Praia do Forte através de uma dinâmica participativa entre alunos e professores do Ensino Fundamental II.

Os trabalhos foram conduzidos através da metodologia dialógica, baseada no trabalho de Paulo Freire, no qual educando e educador, pelo diálogo, fazem trocas de conhecimentos, transformando-os em um novo conhecimento usando a açãoreflexão-ação durante o processo.

A relação entre meio ambiente e educação para a cidadania admite uma função cada vez mais desafiadora, convocando a emergência de novos saberes para apreender processos sociais mais complexos e riscos ambientais que se intensificam.

Nas últimas décadas nota-se que as pressões sobre o ambiente global tornaram-se evidentes, fazendo-se necessário promover atitudes que zelem pelo desenvolvimento sustentável.

Essa estratégia requer um novo enquadramento mental e novo conjunto de valores. Um caminho para a promoção desse desenvolvimento é a educação ambiental, que pretende aumentar a capacidade das pessoas de enfrentar as questões ambientais e de desenvolvimento de forma mais harmônica possível.

Para os profissionais envolvidos com o tema da educação ambiental, o desafio é formular uma metodologia que desperte a capacidade crítica e inovadora dos participantes. Assim as ações devem ser acima de tudo um ato político voltado para a transformação social.

O educador deve estar capacitado para atuar como catalisador de processos educativos que respeitem a pluralidade e diversidade cultural fortalecendo a ação coletiva, articulando aportes de diferentes saberes e fazeres, e proporcionando a compreensão individual e coletiva da problemática ambiental em toda a sua complexidade.

Diferentes conceitos, objetivos e abordagens, inviabilizam falar de uma única educação como a mais adequada. Educação é estimular a sede de conhecimentos. 
O educador e o educando aprendem do seu contato mútuo. A verdadeira educação é a que é experimentada, provocada e dirigida.

Para intervir na realidade foram utilizados métodos e princípios de ações, valendo-se igualmente de técnicas, atitudes e habilidades. Foram dada ênfase à participação comunitária e a pesquisa-ação. Nesse projeto, o poder argumentativo é válido e quebrou a rigidez de uma pesquisa tradicional. Essa linha de pensamento está associada a diversas formas de ação coletiva voltada para resolução de problemas ou de objetivos de transformação.

A atuação teve como escolha a utilização da metodologia participativa, a qual foi compreendida como aquela capaz de envolver os participantes na construção da cidadania crítica e responsável. Não considerar as pessoas como objetos de investigação, mas as estimula a trabalharem juntas, como sujeitos conscientes, criativos e comprometidos com a transformação da realidade.

As ações socioeducativas desenvolvidas na escola objetivaram possibilitar a ampliação da compreensão do corpo docente e discente do seu papel e sua responsabilidade com o ambiente. A linha de condução do Projeto partiu do princípio de que as propostas pedagógicas têm que ser construídas pelos próprios educadores, em parceria com os educandos.

As mudanças comportamentais não acontecem apenas com a teoria, demandando por parte da escola o exemplo em processos e ações extra aula que estejam de acordo com os conteúdos abordados pelos professores. A simples repetição de conceitos teóricos não é suficiente para a construção de uma nova consciência em relação ao meio ambiente.

O principal objetivo de atuação da educação ambiental deve conquistar, acima de tudo, a solidariedade, a igualdade e o respeito à diferença através de formas democráticas de atuação baseadas em práticas interativas e inovadoras. 


\section{REFERÊNCIAS}

BRASIL. Lei 9.795, de 27 de abril de 1999. Institui a Política Nacional de Educação Ambiental. Brasília: Diário Oficial da União, 28 de abril de 1999.

Decreto $n^{\circ}$ 73.030, de 30 de Outubro de 1973. Institui a Política Nacional de Educação Ambiental. Brasília: Diário Oficial da União, 28 de abril de 1999.

. Ministério do Meio Ambiente. Lei n. 6.938, de 31 de agosto de 1981. Política Nacional do Meio Ambiente.

Decreto $\mathrm{n}^{\circ} \mathbf{7 3 . 0 3 0}$, de 30 de Outubro de 1973. Institui a Política Nacional de Educação Ambiental. Brasília: Diário Oficial da União, 28 de abril de 1999.

\section{. Constituição da República Federativa do Brasil de 1988.}

CARVALHO, I. C. M. Educação ambiental: a formação do sujeito ecológico. 2.ed. São Paulo: Cortez, 2006.

CHALITA, Gabriel. Educação: a solução está no afeto. São Paulo: Gente, 2002.

COOPERMARC - Cooperativa de Materiais Recicláveis de Camaçari, 2014. Controle de resíduos sólidos de evento.

DIAS, G. F. Educação ambiental: princípios e práticas. 9a ed. São Paulo: Gaia, 2004.

EFFTING, T. R. Educação Ambiental nas Escolas Públicas: realidade e desafios. Monografia. Marechal Cândido Rondon, Universidade Estadual do Oeste do Paraná, 2007.

EMBASA. Controle de indicadores de ações socioambientais. Relatório de sustentabilidade. 2014. 
GAUTHIER, C; MALO, A; SIMARD, D; DESBIENS, J-F; MARTINEAU, S. Por uma teoria da pedagogia: pesquisas contemporâneas sobre o saber docente. ljuí: Ed. UNIJUÍ, 1998. (Coleção fronteiras da educação).

GUIMARÃES, M.; VASCONCELLOS, M. das M. N. Relações entre educação ambiental e educação em ciências na complementaridade dos espaços formais e não formais de educação. Educar, Curitiba, n. 27, p. 147-162, 2006. Editora UFPR

JACOBI, Pedro. Educação Ambiental, Cidadania e Sustentabilidade. USP. Cadernos de Pesquisa, n. 118, março, 2003.

MARTINS, Gilberto de Andrade. Estudo de caso: uma estratégia de pesquisa. 2 . Ed. São Paulo Atlas. 2008, p. XI

MENDES, Regina; VAZ, Arnaldo. Educação em Revista. Belo Horizonte, v.25, n.03, p.395-411, dez. 2009

REIGOTA, Marcos. O que é educação ambiental. 2. ed. São Paulo: Brasiliense, p.15, 2009.

SOUZA, A. K. A relação escola-comunidade e a conservação ambiental. Monografia. João Pessoa, Universidade Federal da Paraíba, 2000.

VARINE, Hugues de. O Ecomuseu. Ciências e Letras, n. 27, p. 61-90, 2000 